ECCOMAS

Proceedia $8^{\text {th }}$ ECCOMAS Then

COMPDYN 2021 Computational Methods in Structural Dynamics and Earthquake Engineering

M. Papadrakakis, M. Fragiadakis (eds.) Streamed from Athens, Greece, 28 - 30 June 2021

\title{
PSEUDO-DYNAMIC ANALYSES OF INFILLED REINFORCED CONCRETE FRAMED STRUCTURES WITH PRIOR DAMAGES AFTER ADVANCED RETROFIT
}

\author{
Theodoros Rousakis $^{1}$, Evgenia Anagnostou ${ }^{1}$, and Theodora Fanaradelli ${ }^{1}$ \\ ${ }^{1}$ Democritus University of Thrace, Department of Civil Engineering, \\ Xanthi, Greece \\ e-mail: \{trousak,eanagno,tfanarad\}@civil.duth.gr
}

\begin{abstract}
This study investigates suitable models for the analysis of innovative retrofits in infilled (and bare) reinforced concrete frames. It focuses on the detrimental effects of prior damages and deficiencies in frames such as corroded steel reinforcements or inadequate lap-splices in columns that may lead to premature failures and structural collapses. It investigates numerically the beneficial effects of innovative interventions on deficient $R C$ frames, through pseudodynamic 3-dimensional finite element analyses. The intervention involves infill wall with special thermal insulating clay brick orthoblocks, having at the boundary interface with the RC frame, an advanced seismic joint made of highly deformable polyurethane. The technique has been already validated experimentally in frames without corroded or lap-spliced bars [1] (as well as for a four-column structure in project named "INfills and MASonry structures protected by deformable POLyurethanes in seismic areas" - INMASPOL [2,3]). The analyses suggest that the 3 dimensional FE models may reproduce with satisfactory accuracy the mechanical behavior of FRP retrofitted deficient columns. Further, they suggest that the deficient $R C$ frames after the innovative composite retrofit achieve higher base shear load than the original bare RC frame without corroded or lap-spliced bars, at comparable top displacement ductility.
\end{abstract}

Keywords: Finite Element, retrofit, reinforced concrete frame, brick infill, polyurethane seismic joint 


\section{INTRODUCTION}

Reinforced concrete (RC) structures in seismic and coastal regions often present accumulated damage due to corrosion of steel reinforcement [4] among others. Further, the columns may include several deficiencies such as inadequate lap-splices of bottom steel bars $[5,16]$ among others. Available innovative materials and intervention techniques such as steel fiber systems or fiber reinforced polymers (FRPs) in the form of sheets, strips and ropes are widely used. Suitable diagnosis and retrofit of deficient members can improve their strength, delay further corrosion of the reinforcement as well as reduce deformations at the serviceability limit stage [5-11, 17].

Furthermore, the behavior of RC frames with masonry infills is significantly affected by the stiffness and the difference in yield-failure deformation between the RC frames and the masonry infills. The majority of buildings are constructed by brittle materials (clay bricks or concrete). Flexible frames cannot support high loads at low excitations and this can cause damage to the infills in normal (frequent) earthquakes. In the case of aftershocks, damaged infills may fail in and/or out of plane and collapse, causing human injuries. On the other hand, if the infill is too strong compared to the columns, it may cause their detrimental shear failure. Seismic isolation of the infills through structural Polyurethane Flexible Joints (PUFJ) may result in desirable RC frame - infill interaction enhancing the elastic stiffness and base shear while maintaining significant displacement ductility of the composite frames [1-3]. PUFJs can be used to fill cracks or joints or to bond composite materials (for masonry see [12]). In cases the fiber retrofit is applied with standard epoxy resins or inorganic matrices, the sequence of failures of the infilled RC frames remains unchanged, revealing a significant accumulation of damage for relative displacement of the frame between $0.5 \%-1.5 \%$ [13]. Recent analytical studies have shown that strengthening with PUFJs may delay infill damage and thus enables the engagement of multiple different infills in a building frame. This aspect increases their shear capacity significantly [3].

However, during an experimental campaign involving large scale frames, only a few parameters can be investigated due to the high demand of resources and time. 3D finite element modelling and analyses may help address the effects of critical design parameters or deficiencies or damages in frames, by further developing already validated models in RC columns and in half RC column-foundation specimens retrofitted or not (see [14,15]).

This study investigates analytically the performance of bare RC frames with corroded reinforcements or inadequate bar lap-splices. Further, their corresponding RC frame counterparts with an innovative infill and PUFJ seismic joint are included in the parametric investigation. The infill wall is made of special thermal insulating clay bricks (orthoblocks with vertical direction of holes), having at the boundary interface with the RC frame an advanced seismic joint made of highly deformable polymer (PUFJ). The technique has been already validated experimentally in frames without corroded or lap-spliced bars in [1] (as well as for a fourcolumn structure in INMASPOL [2,3]). The parametric analyses reveal the effects of damages and deficiencies on the performance of seismic resistant frames and the potential of innovative retrofits with seismic polymer joints.

\section{FINITE ELEMENT MODELLING}

This study develops suitable models for the analytical investigation of innovative retrofits in infilled (and bare) framed structures with prior structural deficiencies, based on the prior numerical validation of 3D FE models of isolated columns with deficiencies. 


\subsection{Concrete}

The behavior of concrete is captured with the Riedel-Hiermaier-Thoma (RHT) model [1820] (ANSYS, Autodyn [21]), suitable for similar geological materials under dynamic loading situations. The RHT is a constitutive model for brittle materials and is a combined plasticity and shear damage model in which the deviatoric stress in the material is limited by a generalized failure surface of the form (Eq. 1)

$$
f\left(P, \sigma_{e q}, \theta, \dot{\varepsilon}\right)=\sigma_{e q}-Y_{T X C(P)} * F_{C A P(P)} * R_{3(\theta)} *(F)_{R A T E(\dot{\varepsilon})}
$$

where $\sigma_{e q}$ is the uniaxial compressive strength, $\mathrm{Y}_{\mathrm{TXC}(\mathrm{p})}$ is the fracture surface, $\mathrm{F}_{\mathrm{CAP}(\mathrm{P})}$ is a dimensionless cap function which activates the elastic strength surface within the RHT mate-

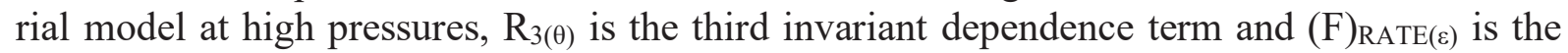
strain rate effect represented through fracture strength with plastic strain rate.

\subsection{Longitudinal and Transverse Steel Bars}

In Explicit Dynamics analyses, plastic deformation is computed by reference to the Von Mises yield criterion (also known as Prandtl-Reuss yield criterion). This states that the local yield condition is (Eq. 2)

$$
\left(\sigma_{1}-\sigma_{2}\right)^{2}+\left(\sigma_{2}-\sigma_{3}\right)^{2}+\left(\sigma_{3}-\sigma_{1}\right)^{2}=2 Y^{2}
$$

where $\sigma_{1}, \sigma_{2}, \sigma_{3}$ are the first, second and third principal stresses and $\mathrm{Y}$ is the yield stress of steel reinforcement under tension.

For the elastic part of the response of the longitudinal and transverse steel was chosen the "Isotropic Elasticity" model. The "Bilinear Isotropic Hardening" model was used to define the yield stress $(\mathrm{Y})$ as a linear function of plastic strain, $\varepsilon_{\mathrm{p}}$ (Eq. 3)

$$
Y=Y_{0}+A^{*} \varepsilon_{p}
$$

where $\mathrm{Y}_{0}$ is the yield strength and $\mathrm{A}$ is the tangent modulus.

\subsection{Brick}

Brick is modeled with Young's modulus equal to $3800 \mathrm{MPa}$ and Poisson's Ratio equal to 0.25 . The orthotropic elasticity material properties with tensile strength in $\mathrm{X}, \mathrm{Y}$ and $\mathrm{Z}$ directions are 1.49 $\mathrm{MPa}, 3.89 \mathrm{MPa}$ and $1.49 \mathrm{MPa}$, respectively.

\subsection{Fiber Reinforced Polymers (FRP)}

The retrofitted isolated specimens were externally confined with 2 layers of carbon FRP [5]. The FRP jacket was applied over a height of $600 \mathrm{~mm}$ at the base of the column. The thickness of one layer of CFRP was $t_{\mathrm{f}}=0.13 \mathrm{~mm}$, the elastic modulus was $\mathrm{E}_{\mathrm{f}}=230 \mathrm{GPa}$ and the failure strain was $\varepsilon_{\mathrm{uf}}=0.015$, while the corners of the section were rounded with radius of $\mathrm{r}=30 \mathrm{~mm}$. FRP jacket was modelled as an orthotropic elastic material. For the analyses, the material properties were reduced to $59,160 \mathrm{MPa}$ for the elastic modulus along the direction of carbon fibers in order to take into account both the fibers and impregnation polymer. In addition, the thickness of the jacket was suitably increased so that the elastic modulus multiplied by the thickness of the jacket, in both cases, provides the same axial rigidity value. 


\subsection{Polyurethane}

The frame specimen is the brick infilled RC frame with polymer joints of $2 \mathrm{~cm}$ thick at 3 sides, simulating application to existing buildings. The 3-sided gap was filled in with PUFJ polymer through by injection. Polymer for PUFJ was of type Sika PM. The elastic modulus, strength and ultimate elongation of the polymer were $4 \mathrm{MPa}, 1.4 \mathrm{MPa}$ and $110 \%$, respectively in a tensile test and the Poisson ratio 0.47. Polyurethane is modeled as an isotropic elasticity material.

\subsection{Element Type}

Concrete and bricks were eight-node elements "Hexahedral Solid Elements". The internal steel reinforcement was 2-node element "Beam (Line) Elements" with the ability to develop large axial deformations. More details on the FE modelling and analysis procedure can be found also in $[14,15]$.

\section{VALIDATION OF FE MODELS}

The analytical study presented herein includes two phases. At the first phase the accuracy of the prediction performance of the constructed 3D FE models are validated against the experimental results of 2 selected real scale RC frames from the study by [1]. Specimen A1F is the bare RC frame of the series and it is designed according to current Eurocodes. This real scale frame has plane dimensions of $270 \mathrm{~cm}$ long beam with extensions of $30 \mathrm{~cm}$ in both sides and height of $245 \mathrm{~cm}$ (245 cm to the level of the diaphragm). The columns are of cross section dimensions of $25 \mathrm{~cm} \times 25 \mathrm{~cm}$ and have $8 \Phi 16$ longitudinal continuous rebars (without lapsplices) and $\Phi 10 / 100 \mathrm{~mm}$ closed stirrups (peripheral and rhombic). The columns have two top extensions of $30 \mathrm{~cm}$ as well as a common foundation beam with dimensions $30 \mathrm{~cm} \times 40$ $\mathrm{cm} \times 355 \mathrm{~cm}$. The top beam has cross section dimensions of $25 \mathrm{~cm} \times 25 \mathrm{~cm}$ and is reinforced with $8 \Phi 14$ longitudinal rebars and $\Phi 10 / 100 \mathrm{~mm}$ closed stirrups (peripheral). The dimensions of the RC frame and the detailing of the internal steel reinforcement are depicted in Figure 1a.

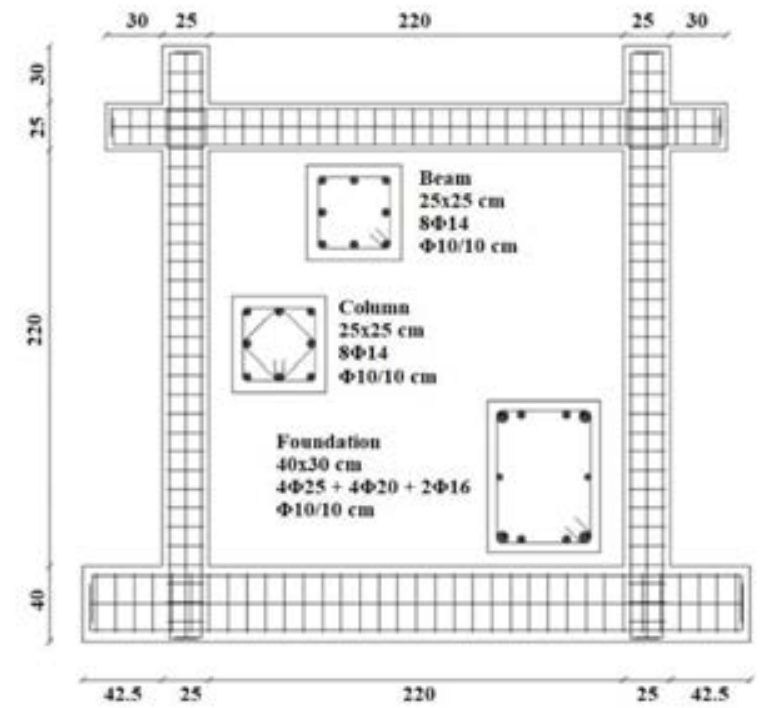

(a)

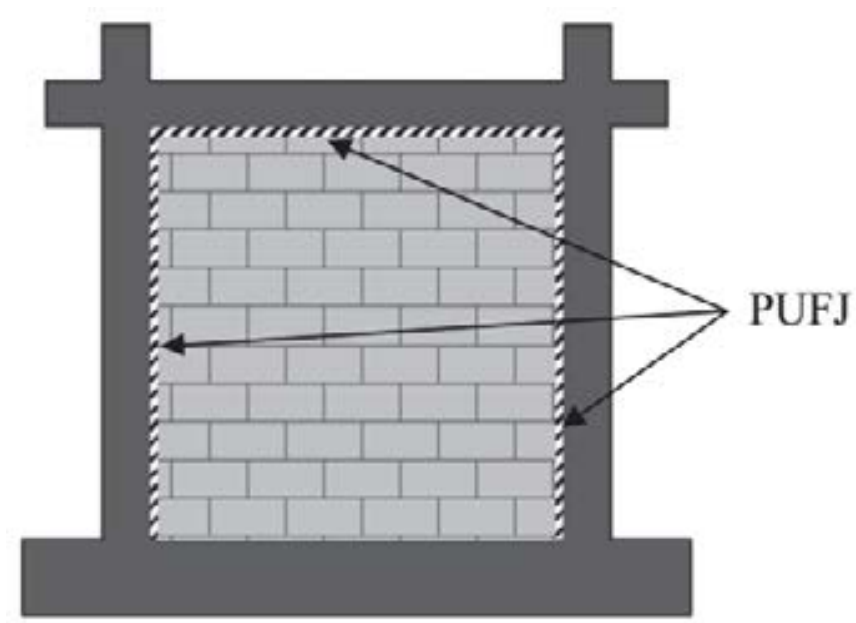

(b)

Figure 1: (a) Dimensions of the RC frame and detailing of internal steel reinforcement and (b) Specimen B2 with 3 -sided polymer joint applied on existing infill (adapted by [1]). 
Specimen B2 is identical to the A1F frame with addition of infill wall with special thermal insulating clay bricks (orthoblocks with vertical direction of holes), having at the boundary interface with the RC frame, advanced seismic joint made of highly deformable polymer. The polyurethane joint is $2 \mathrm{~cm}$ thick, placed at 3 sides (at 2 vertical interfaces and at top interface) which is depicted in Figure 1b. The two columns of the frame have been subjected to $375 \mathrm{KN}$ concentric load each. Then, the horizontal actuator imposed cycles of gradually increased displacements at the top beam. More details on the experimental setup and test results of the 2 selected frames can be found in [1].

Figures $2 \mathrm{a}$ and $2 \mathrm{~b}$ show in black and black-grey curves the experimental envelope base shear - top displacement curves of the two frames for $(+)$ and (-) push respectively. It should be mentioned that the innovative orthoblock infill with the PUFJ seismic joint increased the elastic stiffness of the frame as well as the maximum base shear of the frame from $164 \mathrm{kN}$ (A1F frame push +) and $134 \mathrm{kN}(\mathrm{A} 1 \mathrm{~F}$ frame push -) to $192.8 \mathrm{kN}(\mathrm{B} 2$ frame push +) and 167 kN (B2 frame push -) when the orthoblock-PUFJ is used. Further, the top displacement ductility of the infilled frame B2 was remarkable, with negligible base shear reduction up to $3.5 \%$ drift for push $(+)$.

The analytical predictions of the FE analyses are in red color and compare well with the experimental ones in terms of maximum and ultimate base shear as well as in terms of top displacement at maximum bearing load and at ultimate (see figure 2).

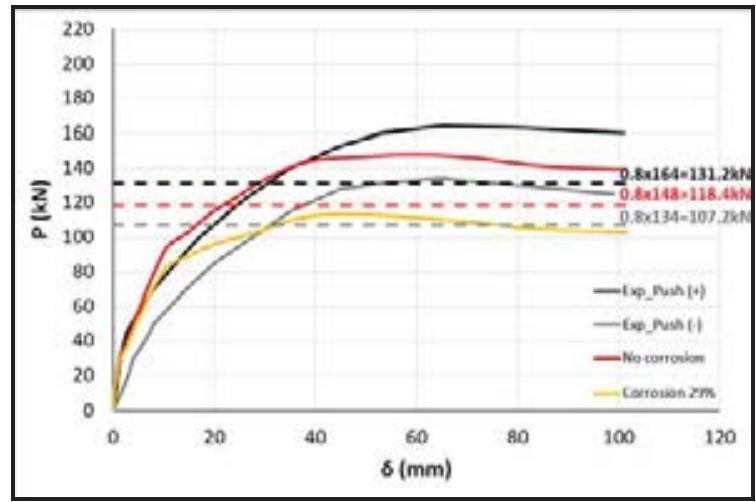

(a)

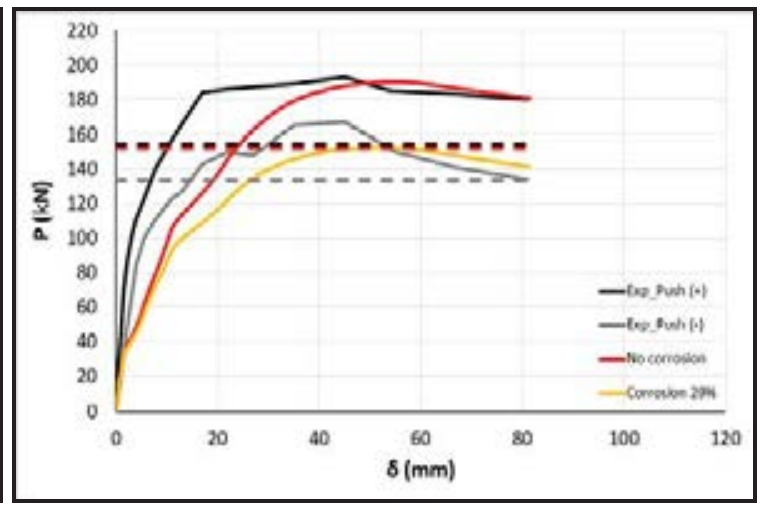

(b)

Figure 2: Analytical base shear force -displacement curve for (a) A1F and (b) B2 with no and 29\% corrosion, compared against the experimental ones.

\section{PARAMETRIC FE ANALYTICAL INVESTIGATION}

At the second phase, the study utilizes the modelling approach presented in [15] for RC columns with lap-spliced steel bars or with corroded reinforcements. The corresponding developments are introduced in the frames $\mathrm{A} 1 \mathrm{~F}$ and $\mathrm{B} 2$ to investigate the effects of the implementation of orthoblock infill with seismic PUFJ on the P-d performance of deficient frames in need of retrofit.

\subsection{Corrosion of steel reinforcement}

Anagnostou and Rousakis [15] validated the simplified FE approach on the analysis of RC columns with corroded steel bars of varying degree of corrosion utilizing the experiments by [5]. The half column specimens had section dimensions $20 \mathrm{~cm} \times 30 \mathrm{~cm}$ and height $120 \mathrm{~cm}$. The concrete strength and steel yield stress was $\mathrm{f}_{\mathrm{c}}=25.5 \mathrm{MPa}$ and $\mathrm{f}_{\mathrm{yL}}=460 \mathrm{MPa}$ and the normalized axial load $v=0.18$. Four different degrees of corrosion were investigated experimen- 
tally. The FE analytical results in [15] suggest there is reduction of the force received by the longitudinal bars under tension compared to the uncorroded column, as the degree of corrosion increases (in accordance with the mass loss of the steel). The strength and the ductility of RC column decrease and the reduction of strain in corroded steel bars is significant. Finally, for a high degree of corrosion, fracture of steel longitudinal bars is expected.

A corrosion of about $10 \%$ results in negligible reduction of the ultimate chord rotation [5] while a higher than $20 \%$ leads to a dramatic reduction of the yielding and ultimate strength. The column NS-X16 presented a reduction in experimental ultimate displacement of about $28 \%$ and in strength about $10 \%$ with respect to uncorroded one. This corrosion level is considered in this study the limit one for a column satisfying the seismic code requirements.

Herein, the analytical and experimental results (for both directions, push + and push -) of specimens NS-X0 and NS-X16 (0 and 16\% corrosion, respectively) for the maximum and ultimate lateral force $\left(\mathrm{P}_{\max }, \mathrm{P}_{\mathrm{u}}\right)$ and the corresponding displacements $\left(\delta_{\mathrm{Pmax}}, \delta_{\mathrm{Pu}}\right)$ are presented and compared in Table 1. The parameter used for the comparisons in all tables is the Absolute Divergence (AD), also known as Absolute Error (AE). It is defined as follows:

$$
A D=\frac{\left|a_{\text {anal. }}-a_{\text {exp. }}\right|}{a_{\text {exp. }}}
$$

$\mathrm{AD}$ requires the absolute experimental values $\left(\alpha_{\text {exp. }}\right)$ to be subtracted by the analytical ones $\left(\alpha_{\text {anal. }}\right)$ and then divided by the experimental ones $\left(\alpha_{\text {exp. }}\right)$. The divergence between the experimental and analytical values at characteristic states for the columns is low (Table 1). All comparisons with loads and displacements at characteristic states suggest the analytical predictions are satisfactory. More details can be found in [15].

\begin{tabular}{lllllll}
\hline & NS-X0 & & & NS-X16 & \\
& Exp. & Anal. & AD (\%) & Exp. & Anal. & AD (\%) \\
\hline$P_{\max }(+)(\mathrm{kN})$ & 60.70 & 54.56 & 10.11 & 50.90 & 49.56 & 2.64 \\
$\delta_{\operatorname{Pmax}}(+)(\mathrm{mm})$ & 20.00 & 20.87 & 4.35 & 18.00 & 42.12 & 134.00 \\
$\mathrm{P}_{\max }(-)(\mathrm{kN})$ & 52.00 & 54.56 & 4.92 & 50.00 & 49.56 & 0.88 \\
$\delta_{\mathrm{Pmax}}(-)(\mathrm{mm})$ & 15.00 & 20.87 & 39.13 & 30.00 & 42.12 & 40.40 \\
$\mathrm{P}_{\mathrm{u}}(+)(\mathrm{kN})$ & 51.60 & 46.38 & 10.12 & 43.27 & 42.13 & 2.63 \\
$\delta_{\mathrm{Pu}}(+)(\mathrm{mm})$ & 81.10 & 73.75 & 9.06 & 55.10 & 52.86 & 4.07 \\
$\mathrm{P}_{\mathrm{u}}(-)(\mathrm{kN})$ & 44.20 & 46.38 & 4.92 & 42.50 & 42.13 & 0.88 \\
$\delta_{\mathrm{Pu}}(-)(\mathrm{mm})$ & 70.00 & 73.75 & 5.36 & 55.00 & 52.86 & 3.89 \\
\hline
\end{tabular}

Table 1: Comparative results for specimens NS-X0 and NS-X16 with different corrosion levels.

The same approach was adopted for the frames A1F and B2. The scenario concerns $29 \%$ mass loss due to corrosion for all the steel bars and stirrups, including the two columns along with the beam. All analyses are stopped at the same displacement, as the experimental one. Figure 2a presents the analytical base shear force - displacement curve of frame A1F with $29 \%$ corrosion while figure $2 \mathrm{~b}$ the curve of B2 with $29 \%$ of corrosion, both in yellow color.

The dashed lines mark the $20 \%$ drop of the maximum values of the analytical and experimental base shears (for both directions, push + and -), considered as the lowest acceptable threshold of base shear at failure according to several seismic codes. In particular (see Table 2 ), for frame $\mathrm{A} 1 \mathrm{~F}$ without corrosion these experimental limit values for push $(+)$ and $(-)$ are $0.8 \times 164=131.2 \mathrm{kN}$ and $0.8 \times 134=107.2 \mathrm{kN}$ respectively. The analytical prediction is $0.8 \times 148=118.4 \mathrm{kN}$, being around the average of experimental ones. Analysis for A1F with 
$29 \%$ corrosion reveals maximum base shear of $113.35 \mathrm{kN}$ which is around the analytical $80 \%$ value at failure for uncorroded frame. Further, the ultimate base shear is $103.26 \mathrm{kN}$, lower than the experimental limits and far lower than the analytical failure limit of $118.4 \mathrm{kN}$. It seems that the base shear degradation at ultimate because of $29 \%$ corrosion in bare frame A1F is $30.2 \%$ (i.e. from $148 \mathrm{kN}$ to $103.26 \mathrm{kN}$ ), concluding corroded $\mathrm{A} 1 \mathrm{~F}$ as insufficient. This load drop is far higher than in isolated columns $(15.6 \%)$ as all steel reinforcements of the frame are considered corroded.

\begin{tabular}{|c|c|c|c|c|c|c|c|}
\hline & \multicolumn{3}{|c|}{ A1F (No corrosion, No lap) } & \multicolumn{2}{|c|}{ A1F $(29 \%$ corrosion $)$} & \multicolumn{2}{|c|}{$\begin{array}{l}\text { A1F (11d d lap } \\
\text { length) }\end{array}$} \\
\hline & Exp. & Anal. & $\mathrm{AD}(\%)$ & Anal. & AD (\%) & Anal. & $\mathrm{AD}(\%)$ \\
\hline $\mathrm{P}_{\max }(+)(\mathrm{kN})$ & 164.00 & 148.00 & 9.76 & 113.35 & 23.41 & 139.67 & 5.63 \\
\hline$\delta_{\text {Pmax }}(+)(\mathrm{mm})$ & 65.00 & 59.93 & 7.80 & 46.25 & 22.83 & 53.34 & 11.00 \\
\hline$P_{\max }(-)(\mathrm{kN})$ & 133.40 & 148.00 & 10.94 & 113.35 & 23.41 & 139.67 & 5.63 \\
\hline$\delta_{\operatorname{Pmax}}(-)(\mathrm{mm})$ & 65.00 & 59.93 & 7.80 & 46.25 & 22.83 & 53.34 & 11.00 \\
\hline $\mathrm{P}_{\mathrm{u}}(+)(\mathrm{kN})$ & 159.90 & 139.14 & 12.98 & 103.26 & 25.79 & 131 & 5.9 \\
\hline$\delta_{\mathrm{Pu}}(+)(\mathrm{mm})$ & 101.50 & 101.50 & - & 101.50 & - & 101.5 & - \\
\hline $\mathrm{P}_{\mathrm{u}}(-)(\mathrm{kN})$ & 124.70 & 139.14 & 11.58 & 103.26 & 25.79 & 131 & 5.9 \\
\hline$\delta_{\mathrm{Pu}}(-)(\mathrm{mm})$ & 99.00 & 101.50 & - & 101.50 & - & 101.5 & - \\
\hline
\end{tabular}

Table 2: Comparative results for specimens A1F with different corrosion levels and lap lengths.

For frame B2 without corrosion, the corresponding experimental limit values for push + and - are $0.8 \times 192.8=154.2 \mathrm{kN}$ and $0.8 \times 167=133.6 \mathrm{kN}$ respectively (Table 3 ). The corresponding analytical prediction is $0.8 \times 190.25=152.2 \mathrm{kN}$, being around the experimental push + value. Analysis for B2 with $29 \%$ corrosion reveals maximum base shear of $152.66 \mathrm{kN}$ which is around the analytical value at failure for uncorroded frame. Further, the ultimate base shear is $141.48 \mathrm{kN}$, which is higher than the limit experimental value for push - direction. However, this base shear degradation at ultimate because of $29 \%$ corrosion, is $25.6 \%$ (i.e. from 190.25 $\mathrm{kN}$ to $141.48 \mathrm{kN}$ ), concluding corroded A1F marginally as insufficient. Interestingly, if B2 frame is considered the retrofitting scenario for A1F corroded bare frame, then the analytical behavior of corroded A1F retrofitted with orthoblock infills and PUFJ (corroded B2) is somewhat better than the analytical behavior of uncorroded A1F. Indeed, the maximum base shear of B2 corroded is $152.66 \mathrm{kN}$ (higher than $148 \mathrm{kN}$ in A1F uncorroded). Further, the ultimate base shear is also higher. Given the unique characteristics of PUFJ for emergency retrofits providing a short curing period of some hours [1-3], this innovative retrofit could enable the corroded frame to sustain P-d demands equivalent to the uncorroded one.

\begin{tabular}{llllllll}
\hline & \multicolumn{3}{c}{ B2 (No corrosion, No lap) } & \multicolumn{2}{c}{ B2 $(29 \%$ corrosion) } & \multicolumn{2}{l}{ B2 (11d bL lap length) } \\
& Exp. & Anal. & AD $(\%)$ & Anal. & AD $(\%)$ & Anal. & AD $(\%)$ \\
\hline $\mathrm{P}_{\max }(+)(\mathrm{kN})$ & 192.80 & 190.25 & 1.32 & 152.66 & 19.76 & 165.04 & 13.25 \\
$\delta_{\operatorname{Pmax}}(+)(\mathrm{mm})$ & 44.80 & 54.70 & 22.10 & 51.70 & 5.48 & 53.72 & 1.79 \\
$\mathrm{P}_{\max }(-)(\mathrm{kN})$ & 166.60 & 190.25 & 14.20 & 152.66 & 19.76 & 165.04 & 13.25 \\
$\delta_{\mathrm{Pmax}}(-)(\mathrm{mm})$ & 44.80 & 54.70 & 22.10 & 51.70 & 5.48 & 53.72 & 1.79 \\
$\mathrm{P}_{\mathrm{u}}(+)(\mathrm{kN})$ & 179.00 & 180.42 & 0.79 & 141.48 & 21.58 & 147.76 & 18.10 \\
$\delta_{\mathrm{Pu}}(+)(\mathrm{mm})$ & 81.40 & 81.40 & - & 81.40 & - & 81.4 & - \\
$\mathrm{P}_{\mathrm{u}}(-)(\mathrm{kN})$ & 134.50 & 180.42 & 34.14 & 141.48 & 21.58 & 147.76 & 18.10 \\
$\delta_{\mathrm{Pu}}(-)(\mathrm{mm})$ & 81.40 & 81.40 & - & 81.40 & - & 81.4 & - \\
\hline
\end{tabular}

Table 3: Comparative results for specimens B2 with different corrosion levels and lap lengths. 
Figures 3 and 4 present the concrete damage of the specimens A1F and B2. Frames A1F with $29 \%$ corrosion and uncorroded present similar damage accumulation. Damage occurs mostly at the bottom and the top of the columns (critical regions) and inside the joints. Specimen B2 with 29\% corrosion presents damage at similar regions but of lower severity as the damage is also distributed inside the orthoblock infill.

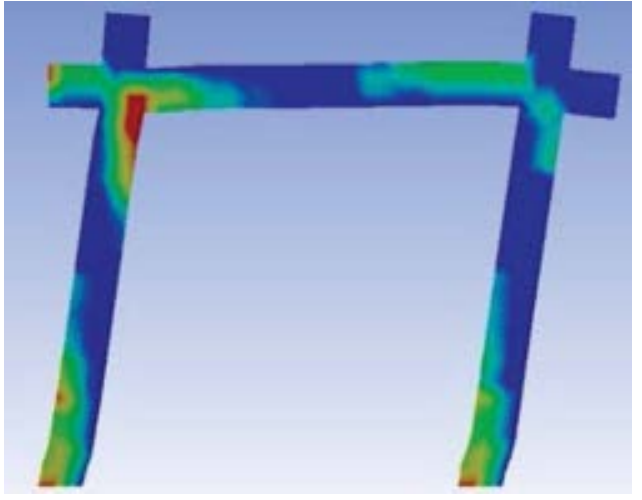

(a)

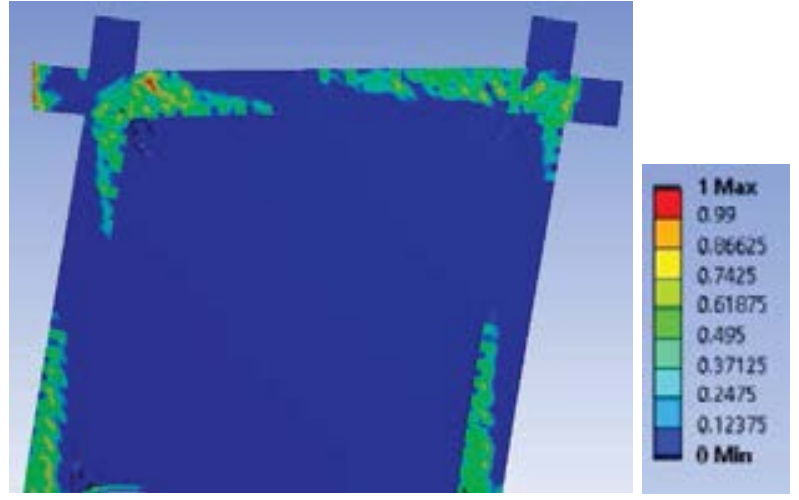

(b)

Figure 3. Concrete damage of specimen A1F with (a) no corrosion/no lap splices, and specimen B2 with (b) no corrosion/no lap splices (magnification factor 2).

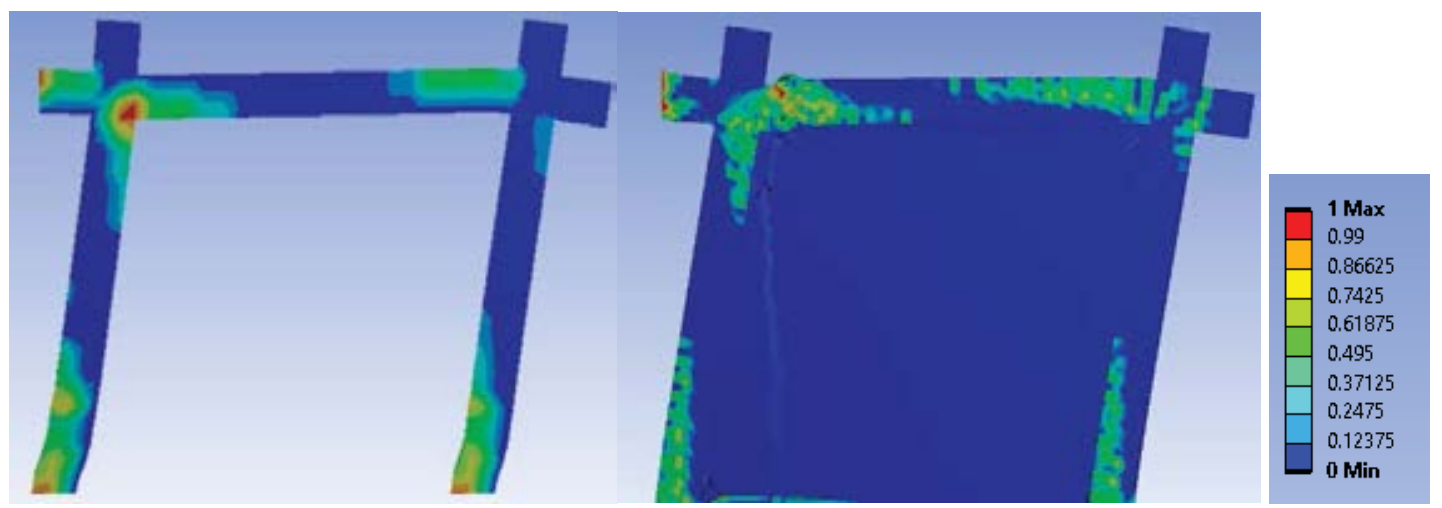

(a)

(b)

Figure 4. Concrete damage of specimen A1F with (a) 29\% corrosion at total displacement $101.50 \mathrm{~mm}$ and specimen B2 with (b) 29\% corrosion at total displacement $81.40 \mathrm{~mm}$ (magnification factor 2).

\subsection{Lap-spliced longitudinal bars}

Anagnostou and Rousakis [15] have verified the 3D FE models of columns with lapspliced longitudinal bars utilizing the experiments by [22]. The half columns had section dimensions $25 \mathrm{~cm} \times 50 \mathrm{~cm}$ and height $160 \mathrm{~cm}$. The concrete strength varied among columns $\mathrm{f}_{\mathrm{c}}=26.9-32.9 \mathrm{MPa}$, and steel yield stress $\mathrm{f}_{\mathrm{yL}}=514 \mathrm{MPa}$. The normalized axial load was $\mathrm{v}=0.26-$ 0.30, while three different lap-splice lengths of 15 times the diameter of the longitudinal bar $\left(15 \mathrm{~d}_{\mathrm{bL}}\right), 30 \mathrm{~d}_{\mathrm{bL}}$ and $45 \mathrm{~d}_{\mathrm{bL}}$ were examined. Table 4 cites the analytical and experimental results of columns with no bar laps or with bar lap lengths of $15 \mathrm{~d}_{\mathrm{bL}}$ and $30 \mathrm{~d}_{\mathrm{bL}}$ confined with 2 layers of FRP. All comparisons with loads and displacements at characteristic states suggest the analytical predictions are satisfactory. Column with $15 \mathrm{~d}_{\mathrm{bL}}$ lap-splices (R-P2L1) shows a significantly reduced base shear (a mean reduction of about 20\%) and reduced deformation capacity 
compared with the column without laps (R-P2L0). Column with $30 \mathrm{~d}_{\mathrm{bL}}$ (R-P2L3), achieves ultimate displacement similar to that of R-P2L0 but at marginally lower base shear (around $4 \%$ ). Similarly, the analytical maximum axial force developed on the bars under tension at the lap region at the base of column R-P2L3 is $134.63 \mathrm{kN}$. This force is $9 \%$ lower than the axial force of $147.89 \mathrm{kN}$ in R-P2L0. For the column R-P2L1 the corresponding axial force is 85.49 $\mathrm{kN}$, being $57 \%$ of the one in column R-P2L0. Therefore, the steel bars in the lap do not yield (analytical yield tensile force on the bar is $130.8 \mathrm{kN}$ ).

\begin{tabular}{llllllllll}
\hline & \multicolumn{1}{l}{ R-P2L0 } & \multicolumn{3}{c}{ R-P2L1 } & \multicolumn{3}{c}{ R-P2L3 } \\
& Exp & Anal & AD $(\%)$ & Exp & Anal & AD $(\%)$ & Exp & Anal & AD (\%) \\
\hline $\mathrm{P}_{\max }(+)(\mathrm{kN})$ & 240.00 & 217.73 & 9.28 & 175.00 & 176.86 & 1.06 & 215.00 & 209.11 & 2.74 \\
$\delta_{\operatorname{Pmax}}(+)(\mathrm{mm})$ & 48.50 & 34.84 & 28.16 & 19.50 & 27.77 & 42.41 & 48.50 & 38.13 & 21.38 \\
$\mathrm{P}_{\max }(-)(\mathrm{kN})$ & 194.00 & 217.73 & 12.23 & 168.00 & 176.86 & 5.27 & 208.00 & 209.11 & 0.53 \\
$\delta_{\operatorname{Pmax}}(-)(\mathrm{mm})$ & 38.50 & 34.84 & 9.51 & 19.00 & 27.77 & 46.16 & 34.50 & 38.13 & 10.52 \\
$\mathrm{P}_{\mathrm{u}}(+)(\mathrm{kN})$ & 192.00 & 174.18 & 9.28 & 140.00 & 141.49 & 1.06 & 172.00 & 167.29 & 2.74 \\
$\delta_{\mathrm{Pu}}(+)(\mathrm{mm})$ & 70.40 & 75.37 & 7.06 & 54.40 & 58.46 & 7.47 & 75.20 & 66.85 & 11.10 \\
$\mathrm{P}_{\mathrm{u}}(-)(\mathrm{kN})$ & 155.20 & 174.18 & 12.23 & 134.40 & 141.49 & 5.27 & 166.40 & 167.29 & 0.53 \\
$\delta_{\mathrm{Pu}}(-)(\mathrm{mm})$ & 64.00 & 75.37 & 17.77 & 50.00 & 58.46 & 16.92 & 65.00 & 66.85 & 2.85 \\
\hline
\end{tabular}

Table 4: Comparative results for specimens R-P2L0, R-P2L1 and R-P2L3 with different lap lengths.

The same approach was adopted for the frames A1F and B2. The scenario concerns the insufficient lap-splice case of $15 \mathrm{~d}_{\mathrm{bL}}$. However, this lap length is further reduced to $11 \mathrm{~d}_{\mathrm{bL}}$ accordingly, based on the different concrete strength of the frames (C30 quality) that corresponds to higher bond strength of the bars inside concrete than the one in the columns by [22] (C20 quality). All analyses are stopped at the same displacement, as the experimental one. Figure 5a presents the analytical base shear force - displacement curve of frame A1F with $11 \mathrm{~d}_{\mathrm{bL}}$ lap length while figure $5 \mathrm{~b}$ the curve of B2 with $11 \mathrm{~d}_{\mathrm{bL}}$ lap length, both in green color.

Analysis for A1F with $11 \mathrm{~d}_{\mathrm{bL}}$ lap length reveals maximum base shear of $139.67 \mathrm{kN}$ (see Table 2) which is only 5.63\% lower than the analytical value at maximum for the frame without laps $(148 \mathrm{kN}$ ). The corresponding ultimate base shear is $131 \mathrm{kN}$ (only $11.4 \%$ lower than $148 \mathrm{kN}$, correspondingly). The ultimate base shear in A1F with laps is higher than all limit values of $20 \%$ drop (experimental or analytical), being sufficient globally, despite insufficient laps. It seems that the base shear degradation at ultimate because of insufficient lap-splices is higher in isolated half column specimens revealing a shear force of $141.49 \mathrm{kN}$. The corresponding maximum base shear in column without lap-splices is $217.13 \mathrm{kN}$, denoting a drop of $34.8 \%$ ( 3 times higher). The reason for this, may be attributed to the engagement of the sections on the top of the columns of the frame at higher extend, to compensate for the insufficiency of the bottom sections (redistribution effects).

Analysis for B2 with 11 d bL lap length reveals maximum base shear of $165.04 \mathrm{kN}$ which is $14.4 \%$ lower than the analytical value at maximum for the frame B2 without laps (Table 3). The ultimate base shear in B2 with laps is $147.76 \mathrm{kN}(22.3 \%$ lower, correspondingly). This value is around the analytical limit value of $20 \%$ drop for frame B2 without laps $(152.2 \mathrm{kN})$, being only marginally insufficient globally, despite heavily insufficient laps. Further, if B2 frame is considered the retrofitting scenario for A1F bare frame with laps, then the analytical behavior of corroded A1F retrofitted with orthoblock infills and PUFJ (corroded B2) is far better than the analytical behavior of A1F without laps. Indeed, the maximum base shear of B2 with laps is $165.04 \mathrm{kN}$ (higher than $148 \mathrm{kN}$ in A1F without laps). Further, the ultimate base shear is $147.76 \mathrm{kN}$ (Table 3), compared with $139.14 \mathrm{kN}$ in A1F without laps (Table 2). 
In this case, orthoblock-PUFJ emergency retrofit [1-4], could enable the lap-spliced frame to sustain P-d demands higher than the A1F frame without laps.

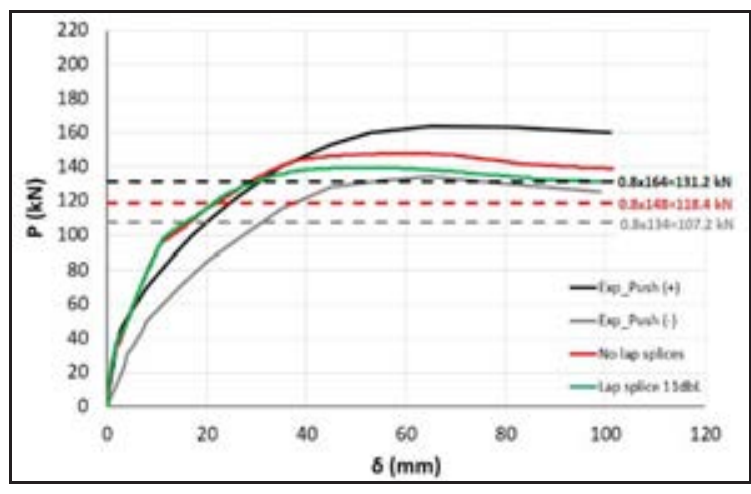

(a)

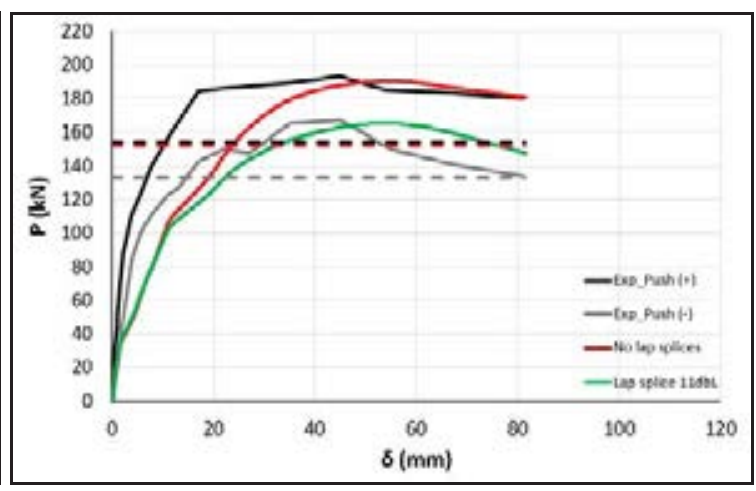

(b)

Figure 5. Analytical base shear force -displacement curve for (a) A1F and (b) B2 with no and $11 \mathrm{~d}_{\mathrm{bL}}$ lap length, compared against the experimental ones.

Figure $6 \mathrm{a}$ presents the undeformed lap length region of $11 \mathrm{~d}_{\mathrm{bL}}$ while figures $6 \mathrm{~b}$ and $6 \mathrm{c}$ the slippage of the bars of frames A1F and B2 at ultimate. In both cases the analyses suggest that the lap-spliced bars reach their yielding force under tension $(96.5 \mathrm{kN})$ despite the slip.

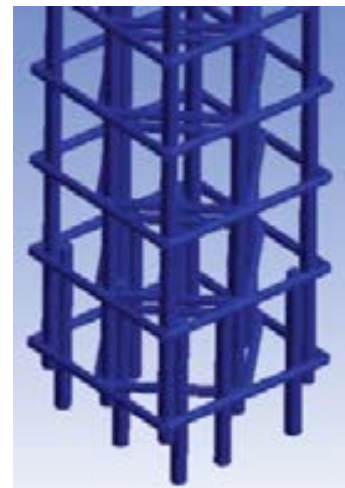

(a)

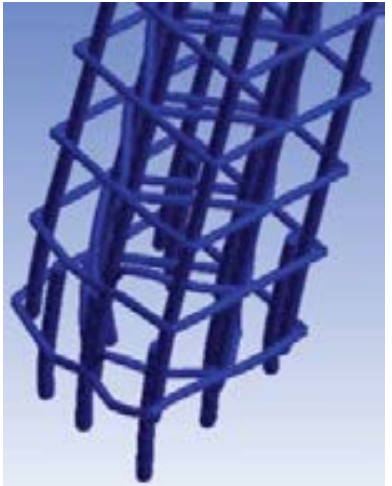

(b)

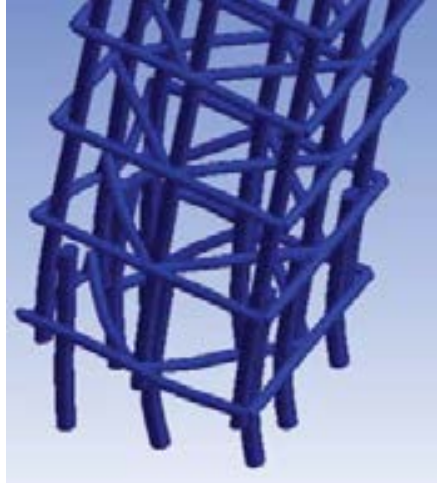

(c)

Figure 6. (a) Undeformed $11 \mathrm{~d}_{\mathrm{bL}}$ lap length, (b) Slippage of longitudinal steel bars of specimen A1F at ultimate displacement of $101.5 \mathrm{~mm}$ and (c) B2 at ultimate displacement of $81.4 \mathrm{~mm}$ (magnification factor 10).

Figures $7 \mathrm{a}$ and $7 \mathrm{~b}$ suggest that both frames present similar damage accumulation. Damage occurs mostly at the bottom and the top of the columns (critical regions) and inside the joints. Specimen B2 with $11 \mathrm{~d}_{\mathrm{bL}}$ lap-splices presents damage of higher severity than in $\mathrm{A} 1 \mathrm{~F}$, at the upper left beam-column joint region and at the bottom of the right column. However, the maximum shear force does not drop below $80 \%$ of the maximum experimental and analytical values. 


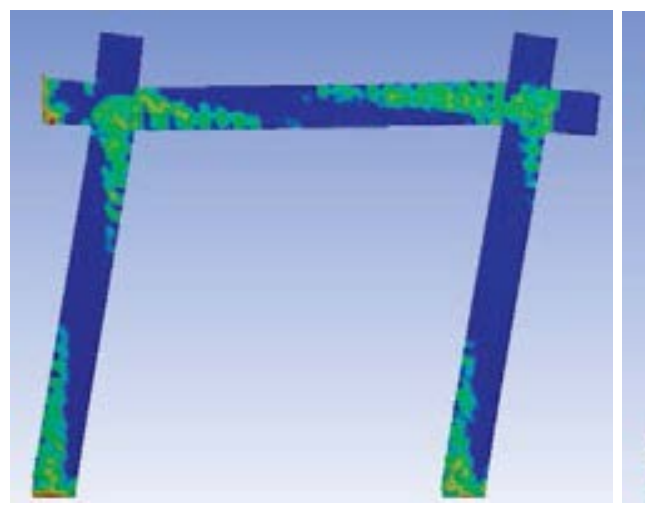

(a)

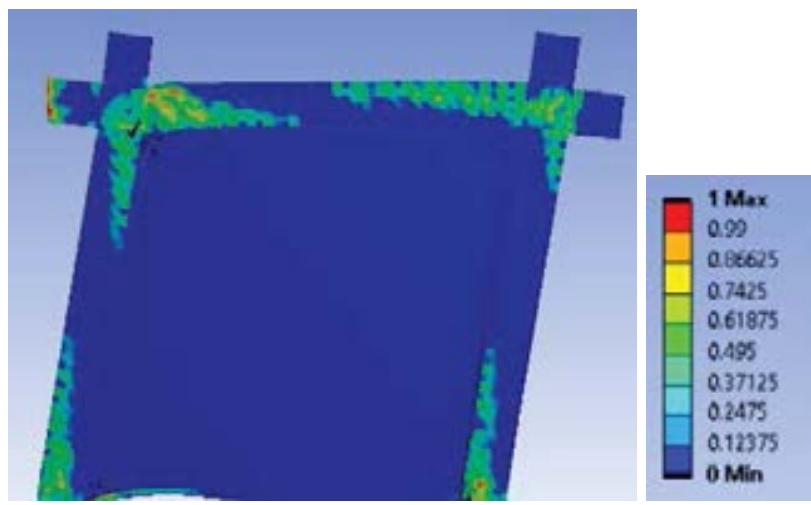

(b)

Figure 7. Concrete damage of specimens with $11 \mathrm{~d}_{\mathrm{bL}}$ lap length of (a) A1F and (b) B2.

\section{CONCLUSIONS}

The analytical results of the developed FE models for frames A1F and B2 compare well with the experimental results. Further, the frames are suitably integrated to assess analytically their performance when they suffer $29 \%$ mass loss of their steel reinforcements due to corrosion or when the bottom column reinforcements have insufficient lap-splices of $11 \mathrm{~d}_{\mathrm{bL}}$ length. Reference experiments of the international literature in half column specimens are utilized to validate the produced models.

The analytical results are mainly assessed based on the lowest acceptable threshold of $20 \%$ drop for the base shear at failure when compared with the maximum base shear of the frame (according to several seismic codes) without damages or deficiencies. Further, the investigated deficiencies cause no significant degradation of the elastic stiffness of the frames.

The corrosion of $29 \%$ steel mass loss to all reinforcements in bare frame A1F, results in ultimate base shear that is $30.2 \%$ lower than the maximum base shear in uncorroded A1F. Therefore, the frame is in need of retrofit as insufficient. In corroded B2 the corresponding drop is lower, $25.6 \%$, considering it marginally as insufficient. However, if corroded B2 is considered the retrofit scenario for corroded A1F with orthoblocks and PUFJ, then the base shear at maximum and at ultimate are both higher than the corresponding values in A1F uncorroded, at comparable top displacement ductility. Therefore, it can be considered an efficient retrofit (especially as emergency one). However, such high levels of corrosion should be treated with caution.

The insufficient lap-splice of $11 \mathrm{~d}_{\mathrm{bL}}$ to the bottom bars of the columns in bare frame A1F results in ultimate base shear that is only $11.4 \%$ lower than the maximum base shear in A1F without laps. The ultimate base shear in A1F with laps is higher than all limit values of $20 \%$ drop (experimental or analytical), being sufficient globally, despite insufficient laps (in isolated half column specimens the drop was 3 times higher). In B2 with lap-splices, the corresponding drop is $22.3 \%$, considering it as marginally insufficient, despite insufficient laps. Further, if B2 frame is considered the retrofitting scenario for A1F bare frame with laps, then the analytical behavior of A1F with insufficient laps and retrofitted with orthoblock infills and PUFJ (B2 with lap-splices) is far better than the analytical behavior of A1F without laps. Orthoblock-PUFJ could enable the frame with lap-splices to sustain P-d demands higher than the A1F frame without laps, at comparable top displacement ductility. 


\section{ACKNOWLEDGMENTS}

This research is co-financed by Greece and the European Union (European Social FundESF) through the Operational Programme «Human Resources Development, Education and Lifelong Learning 2014- 2020» in the context of the project "Advanced Material Retrofits of Infilled Framed Reinforced Concrete Structures With Predamages Against Collapse" (MIS 5050146)

\section{REFERENCES}

[1] A.T. Akyildiz, A. Kwiecień, B. Zając, P. Triller, U. Bohinc, T. Rousakis, A. Viskovic, Preliminary in-plane shear test of infills protected by PUFJ interfaces. $17^{\text {th }}$ International Brick and Block Masonry Conference from Historical to Sustainable Masonry (IB2MaC 2020), Krakow, Poland, July 5-7, 2020.

[2] T. Rousakis, A. Ilki, A. Kwiecień, A. Viskovic, M. Gams, P. Triller, B. Ghiassi, A. Benedetti, Z. Rakicevic, C. Colla, O.F. Halici, B. Zając, L. Hojdys, P. Krajewski, F. Rizzo, V. Vanian, A. Sapalidis, E. Papadouli, A. Bogdanovic, Deformable Polyurethane Joints and Fibre Grids for Resilient Seismic Performance of Reinforced Concrete Frames with Orthoblock Brick Infills. Polymers, 12, 2869, 2020.

[3] T. Rousakis, Brick walls Interventions with FRPU or PUFJ and of RC columns with FR in Brick-Infilled RC Structures with the use of Pushover Beam-Column Element Analysis and Pseudo-Dynamic 3D Finite Element Analysis. $17^{\text {th }}$ International Brick and Block Masonry Conference from Historical to Sustainable Masonry (IB2MaC 2020), Krakow, Poland, July 5-7, 2020.

[4] C. Goksu, A. Ilki, Seismic Behavior of Reinforced Concrete Columns with Corroded Deformed Reinforcing Bars. ACI Structural Journal, 113(5), 1053-1064, 2016.

[5] S.N. Bousias, M.N. Fardis, A.I. Spathis, D. Biskinis, Concrete or FRP jacketing of concrete columns for seismic retrofitting.S.T. Wasti, G. Ozcebe eds. Advances in Earthquake Engineering for Urban Risk Reduction. Nato Science Series: IV: Earth and Environmental Sciences, vol 66. Springer, 2006.

[6] C.G. Papakonstantinou, K. Katakalos, Flexural behavior of reinforced concrete beams strengthened with a hybrid inorganic matrix - Steel fiber retrofit system. Structural Engineering and Mechanics, 31(5), 567-585, 2009.

[7] G.G. Triantafyllou, T.C. Rousakis, A.I. Karabinis, Corroded RC beams patch repaired and strengthened in flexure with fiber-reinforced polymer laminates. Elsevier Journal of Composites Part B: Engineering, 112, 125-136, 2017 a.

[8] G.G. Triantafyllou, T.C. Rousakis, A.I. Karabinis, Analytical assessment of the bearing capacity of RC beams with corroded steel bars beyond concrete cover cracking. Elsevier Journal of Composites Part B: Engineering, 119, 1325-140, $2017 \mathrm{~b}$.

[9] G.G. Triantafyllou, T.C. Rousakis, A.I. Karabinis, Effect of patch repair and strengthening with EBR and NSM CFRP laminates for RC beams with low, medium and heavy corrosion. Elsevier Journal of Composites Part B: Engineering, 133, 101-111, 2018. 
[10] C.E. Chalioris, V.K. Kytinou, M.E. Voutetaki, C.G. Karayannis, Flexural Damage Diagnosis in Reinforced Concrete Beams Using a Wireless Admittance Monitoring System-Tests and Finite Element Analysis. Sensors, 21(3), 679, 2021.

[11] C.G. Karayannis, E. Golias, Full scale tests of RC joints with minor to moderate seismic damage repaired using C-FRP sheets. Earthquake and Structures, 15(6), 617-627, 2018.

[12] B. Zając, A. Kwiecień, Thermal stress generated in masonries by stiff and flexible bonding materials. $9^{\text {th }}$ International Masonry Conference, Guimarães, Portugal, 2014.

[13] L. Koutas, T.C. Triantafillou, S.N. Bousias, Analytical modeling of masonry-infilled $\mathrm{RC}$ frames retrofitted with textile-reinforced mortar. Journal of Composites for Construction, 19(5), 2014.

[14] T.D. Fanaradelli, T.C. Rousakis, 3D Finite Element Pseudodynamic Analysis of Deficient RC Rectangular Columns Confined with Fiber Reinforced Polymers under Axial Compression. Polymers, 12(11), 2546, 2020.

[15] E. Anagnostou, T.C. Rousakis, 3D Finite Element Analysis of FRP Retrofitted Seismic Resistant Reinforced Concrete Columns with Lap Splices or Prior Damages. Submitted for publication, 2021.

[16] G. Kalogeropoulos, A.D. Tsonos, Cyclic performance of RC columns with inadequate lap splices strengthened with CFRP jackets. Fibers, 8(6), 39, 2020.

[17] K. Katakalos, G. Manos, C. Papakonstantinou, Seismic retrofit of R/C T-beams with steel fiber polymers under cyclic loading conditions. Buildings, 9(4), 101, 2019.

[18] W. Riedel, Beton unter dynamischen Lasten: Meso- und makromechanische Modelle und ihre Parameter. Fraunhofer Verlag, 2004.

[19] W. Riedel, N. Kawai, K. Kondo, Numerical Assessment for Impact Strength Measurements in Concrete Materials. International Journal of Impact Engineering, 36, 283-293, 2006.

[20] W. Riedel, K. Thoma, S. Hiermaier, E. Schmolinske, Penetration of Reinforced Concrete by BETA-B-500, Numerical Analysis using a New Macroscopic Concrete Model for Hydrocodes. $9^{\text {th }}$ Internationales Symposium Interaction of the Effects of Munitions with Structures, Berlin Strausberg, Germany, May 3-7, 1999.

[21] ANSYS ${ }^{\circledR}$, Academic Research Release 15.0. SAS IP Inc, Canonsburg, PA, USA, 2003.

[22] S.N. Bousias, T.C. Triantafillou, M.N. Fardis, L. Spathis, B.A. O’Regan BA, Fiberreinforced polymer retrofitting of rectangular reinforced concrete columns with or without corrosion. Structural Journal, 101(4), 512-520, 2004. 